DOI https://doi.org/10.30525/978-9934-26-038-4-44

\title{
THE EFFECT OF INTERMITTENT COLD EXPOSURE AND BROWN ADIPOSE TISSUE ON THE STATE OF ADIPOCYTOKINES IN RATS WITH DEHYDROEPIANDROSTENEDIONE - INDUCED POLYCYSTIC OVARY SYNDROME
}

\author{
Kuzmina I. Yu. \\ Ph. D. in Medicine, \\ Professor at the Department of General \\ and Clinical Pathophysiology by D. O. Alpern \\ Kharkiv National Medical University \\ Zhulikova M. V. \\ Postgraduate Student at the Department of General \\ and Clinical Pathophysiology by D. O. Alperna \\ Kharkiv National Medical University \\ Kharkiv, Ukraine
}

Introduction. Polycystic ovary syndrome (PCOS) is one of the most common diseases in women of reproductive age and includes cystic ovarian degeneration, hyperandrogenism and chronic anovulation [1]. In addition, it is associated with a high risk of developing insulin resistance, obesity, dyslipidemia and cardiovascular disease. Because no etiological factor is able to fully cover all clinical signs, the pathogenesis of PCOS is largely unknown. PCOS has been shown to be associated with the secretion of adinocytokines (leptin and adiponectin) [2]. Leptin activates specific leptin receptors. An important regulator of leptin secretion is hyperinsulinemia (GI). Adipocytes produce leptin in response to increased insulin levels. Adiponectin is secreted by white adipose tissue and affects the release of gonadotropins and can be regulated by insulin and serve as a marker of insulin resistance [3]. One of the possible factors in the pathogenesis of PCOS, at present, is called dysfunction of adipose tissue (even in the absence of obesity), which is primarily associated with insulin resistance. There are two main types of adipose tissue in humans and mammals: white adipose tissue, which stores energy in the body, and brown adipose tissue (BAT), whose main function is thermogenesis and maintaining body temperature under cooling [4].

The aim of the study. To determine the changes in adiponectin and leptin in rats during experimental PCOS before and after intermittent cold exposure and the role of brown adipose tissue in restoring the structure and function of the ovaries on the background of insulin resistance. 
Material and methods. The study was performed on 32 white female rats of the population WAG / GSto, aged 5-6 months, body weight, before the study, $240 \pm 14,5$ grams. To model PCOS, rats were divided into 2 groups: main (25 rats) and control (7 rats). The control group consisted of healthy animals, and was selected to compare the results with the main group. The experiments were performed in accordance with the "General Principles of Animal Experiments», approved by the I National Congress of Bioethics (September 20, 2001, Kyiv, Ukraine) and agreed with the provisions of the Convention on the Protection of Vertebrate Animals for experimental and other scientific purposes.

Modeling of PCOS in rats was performed using exogenous dehydroepiandrostenedione (DHEA). In this case, the mechanism of insulin resistance is receptor. Due to the increase in the area of adipocytes there is a decrease in the number of insulin receptors per unit area. The level of sex hormones, insulin, antimullerian hormone (AMG) in rats was determined by ECLIA immunoassay using automatic analyzers and reagents from Roche Diagnostics (Germany) and enzyme-linked immunosorbent assay of Immunotech kits (Czech Republic). The concentration of adipocytokines in the serum was determined by enzyme-linked immunosorbent assay using the sandwich method (ELISA) with a kit manufactured by Diagnostics Biochem Canada Inc.

Intermittent cold exposure (ICE) was carried out by keeping the animals for 4 hours in a chamber in which the light regime and a temperature of $+4 \mathrm{C}$. The remaining $20 \mathrm{~h}$ of the animal were under normal conditions of ambient temperature and light regime. Rats were cooled daily for 20 days.

Statistical processing of the obtained data was performed using the software package Statistica10.0 (StatSoftInc., USA).

Results. Hormonal examination of rats with experimental PCOS showed a significant increase in peripheral blood luteinizing hormone (LH), ovarian androgens, a tendency to decrease the level of estrodiol (ES) and insufficient content of folliculo-stimulating hormone $(\mathrm{FSH})$ and progesterone $(\mathrm{p}<0,01)$. It was determined that adiponectin does not affect the concentration of FSH, but reduces the secretion of LH.

In our study, we found that the level of adiponectin in the serum of rats of the control group increases, in accordance with the increase in the concentration of antimullerian hormone (AMG) and $\mathrm{LH}$.

The concentration of leptin in the blood increased proportionally with the degree of obesity and insulinemia. In particular, in rats of the main group with experimental PCOS, the insulin content was almost 2,5 times higher than in rats of the control group. Decreased levels of adiponectin and increased leptin concentrations in rats of the main group compared with the control group, confirm the dysfunction of adipose tissue of rats with PCOS.

Morphometric analysis allowed a quantitative assessment of changes in the cytomorphological profile of adipocytes of the BAT under intermittent cold exposure. A significant decrease in the number of adipocytes in the 
BAT of animals compared with the control. Visually, BAT acquired a denser packaging and a pronounced dark brown color. There was a significant decrease in the area of adipocytes in rats of the experimental group with PCOS, in which in adipocytes of the same type there was a significant decrease in the diameter of lipid vacuoles after the animals were subjected to ICE. Summarizing the results, it can be noted that under the influence of cold in BAT animals are adaptive reactions aimed at mobilizing lipid reserves to generate heat. This is expressed in a decrease in the number of adipocytes, as well as the area of cells and the diameter of lipid droplets in them.

Our results coincide with those of other authors who observed similar morphological changes in BAT in rats under cold exposure. With the introduction of DHEA, changes are observed, which can also be described as the activation of BAT in the preservation of the morpho-functional state of the ovaries in experimental PCOS. This was expressed in the fact that the transplantation of BAT in rats on the background of the introduction of DHEA decreased the formation of cysts in the ovaries, while in the case of BAT transplantation, ovarian cysts are formed in approximately $85 \%$ of animals.

This may indicate a protective effect of activated BAT on the regulation of follicle maturation. It is known that rats injected with exogenous DHEA are characterized by a significant decrease in energy metabolism. The mechanism of influence of BAT on DHEA-induced cyst formation in the ovaries is associated with the secretion of adipocytokines (leptin, adiponectin) and other systemic regulators of metabolism.

The level of adiponectin decreased in rats with experimental PCOS on the background of induced cyst formation in the ovaries, possibly due to other systemic regulators of metabolism. ICEleads to increased levels of adipocytokines, which may indirectly affect the secretion of reproductive hormones and prevent the development of cystic changes in the ovaries.

Conclusions. Experimental polycystic ovaries syndrometo degenerative cystic changes in the ovaries of rats, which contributes to the secretion of gonadotropic hormones and indicators of adiponectin and leptin associated with insulin resistance.

Intermittent cold exposures and brown adipose tissue transplantation help to restore the structure and function of ovarian tissue, normalizetion the synthesis of adipocytokines and prevent the development of polycystic ovary syndrome.

\section{References:}

1. Robin G. Polycystic Ovary-Like Abnormalities (PCO-L) in women with functional hypothalamic amenorrhea. J. Clin Endocrinol Metab. 2012. - Nov. № 97(11). P. 4236-4243.

2. Y. Zhang.Irisin Stimulates Browning of white adipocytes through mitogen-activated protein kinase p38 MAP kinase and ERK MAP kinase signaling.J. Diabetes. - 2014. Feb. Vol. 63. № 2. - P. 514-525. 
3. Lord G.M., Matarese GI., Howard J.K. et al. Leptin modulates the T-cell immune response and reverses starvation-induced immunosuppression. Nature. - 2018. - Vol. 394. - P. 897-901.

4. Houde A.A. Leptin and adiponectin DNA methylation levels in adipose tissues and blood cells are associated with BMI, waist girth and LDL-cholesterol levels in severely obese men and women. BMC Med. Genet. - 2015. - Vol. 16. - P. 29.

DOI https://doi.org/10.30525/978-9934-26-038-4-45

\title{
ВИЯВЛЕННЯ СТУПЕНЯ АДАПТАЦІЇ ІМУННОЇ СИСТЕМИ ДО ФІЗИЧНИХ НАВАНТАЖЕНЬ
}

\author{
Луковська О. Л. \\ кандидат медичних наук, \\ професор кафедри фізіології та спортивної медицини \\ Придніпровська державна академія фізичної культури і спорту \\ Кудрявцева В. С. \\ кандидат біологічних наук, \\ дочент кафедри фізіології та спортивної медицини \\ Придніпровська державна академія фізичної культури і спорту \\ Бурдаєв К. В. \\ старший викладач кафедри фізіології та спортивної медицини \\ Придніпровська державна академія фізичної культури і спорту

\section{Петречук Л. М.} \\ кандидат медичних наук, \\ дочзент кафедри фізіології та спортивної медицини \\ Придніпровська державна академія фізичної культури і спорту

\section{Мізін В. В.} \\ викладач кафедри фізіології та спортивної медицини \\ Придніпровська державна академія фізичної культури і спорту \\ м. Дніпро, Україна
}

Надмірні тренувальні навантаження пригнічують нормальну функцію імунної системи, підвищуючи сприйнятливість перетренованого організму спортсмена до інфекційних захворювань. Результати числен- 